\title{
Cervical Effacement
}

National Cancer Institute

\section{Source}

National Cancer Institute. Cervical Effacement. NCI Thesaurus. Code C92751.

A shortening and thinning of cervix due to the action of uterine contractions during active labor to allow for fetal descent. 